\title{
Letter to the editor: Possible role of topical povidone iodine in case of accidental ocular exposure to SARS-CoV-2
}

\author{
Phulen Sarma $^{1} \cdot$ Hardeep Kaur ${ }^{1} \cdot$ Bikash Medhi $^{1} \cdot$ Anusuya Bhattacharyya ${ }^{2}$ (i) \\ Received: 17 July 2020 / Revised: 17 July 2020 / Accepted: 23 July 2020 / Published online: 29 July 2020 \\ (C) Springer-Verlag GmbH Germany, part of Springer Nature 2020
}

We read the letter by Agarwal R et al. very carefully and appreciate them for nicely addressing the issues; however, we have some concerns. The authors have expressed their concern about presence of the virus in ocular secretions; however, although the prevalence is low, the presence of SARS$\mathrm{CoV}-2$ in ocular fluid is well-established. Even some patients have showed strong positivity for the virus in ocular fluid [1]. In a study, around $31.6 \%$ of the patients showed ophthalmologic manifestations similar to conjunctivitis and $16 \%$ of the patients showed SARS-CoV-2 positivity in ocular fluid [2]. A systematic review and meta-analysis have already established this issue [3]. The low prevalence of ocular fluid positivity for SARS-CoV-2 may be due to many reasons. The timing of sample collection is very important in this regard [1]. Many authors report that viral secretion can be seen only during the early phases $[1,4]$. Again, sample collection may be inadequate and ocular surface swab samples collected few exfoliated cells which had a low chance of detecting the virus [1]. Again, low sensitivity of the RT-PCR-based diagnostic kits can also contribute to the low detection rate [1].

Agarwal $\mathrm{R}$ et al. also mentioned their concern regarding uncertainty about the ability of the virus into the systematic circulation through that through accidental hand-eye contact. Although we do not have data regarding occurrence of

\author{
Anusuya Bhattacharyya \\ anusuya.8k@gmail.com \\ Phulen Sarma \\ phulen10@gmail.com \\ Hardeep Kaur \\ Aspireachieve.shine@gmail.com \\ Bikash Medhi \\ drbikashus@yahoo.com
}

1 Department of Pharmacology, PGIMER, Chandigarh, India

2 Department of Ophthalmology, Government Medical College and Hospital, Sector 32, Chandigarh, India
COVID-19 from accidental hand eye exposure, however there is a report of occupational ocular exposure to SARS-CoV-2 (owing to dislodged eye goggles) that led to development of COVID-19 in a nurse who used a dislodged eye goggles [5]. However, we have data from rhesus macao [6], which proves that ocular inoculation may lead to establishment of an infection. In animals with conjunctival inoculation, high concentration of SARS-CoV-2 was noted in the nasolacrimal duct (NLD). Establishment of systemic infection was noted with both the route of inoculation (intra-tracheal and conjunctival inoculation) [6].

Again, the authors have expressed their concern regarding the doubtful presence of and action of ACE2 receptor in corneal and conjunctival epithelium. We all know that both ACE2 and TMPRSS2 are required for a successful establishment of a human infection [7-9]. A study by Ma et al. 2020 raised concern against the expression of TMPRSS2 in conjunctival cells and commented that conjunctiva is less likely to be infected with the virus (data generated in mouse cornea and human primary conjunctival and pterygium cell lines) [8]. Another point to be considered is that mRNA expression level differs between in vivo state and in culture [10,11]. In human cell lines, although ACE2 was present in the conjunctival cell lines, however, they could not locate the expression of TMPRSS2 in the conjunctival cells [8]. Another study has supported these findings [12]. However, many of the other studies report in the opposite. One of the studies published from John Hopkins University School of medicine has confirmed the expression of ACE2 in cornea, limbus, and conjunctiva in surgical and postmortem specimen using immunohistochemistry (IHC). Notably, prominent staining was noted in the epithelial surface of cornea and superficial conjunctival surface. In their study, TMPRSS2 expression was noted in conjunctival specimens. These findings were further validated in western blot analysis [13]. Other studies also confirmed the presence of ACE2 receptor expression in conjunctival tissue $[14,15]$. These studies summarized that COVID-19 may spread through conjunctiva [14]. Another possible route of 
transmission is that the pathogens in the ocular surface might get transported into the nasal and nasopharyngeal mucosa is through the nasolacrimal duct (NLD), which may be the route of entry of the disease [16]. As ACE2 and TMPRSS2 both are present in conjunctiva, the SARS-CoV-2 may take this route or the NLD route to infect the exposed person. WHO has already included the eye as a possible route of direct transmission of the disease through contact and droplet transmission and fomite transmission [17] and thus the ocular route of transmission must not be ignored [18]. Occupational ocular exposure to SARS-CoV-2 leading to COVID-19 is already reported especially in a nurse who used a dislodged eye goggles [5]. Another study supported the role of normal conjunctiva in transmission of COVID-19 [1].
Agarwal $\mathrm{R}$ et al. mentioned about low risk of shredding the virus in ocular secretions and commented that use of prophylactic PVP-I for accidental ocular exposure without gauging the infectivity status of the patient seems a little unrealistic and improbable. We admit that although low, but there is definite evidence of shredding of the virus in ocular secretions [3]. However, the presence or absence of the virus in ocular secretions/scrapings/conjunctival specimens do not correlate well with occurrence of ocular symptoms [3]. In our article, we are talking about accidental exposure through the ocular route e.g. spitting on face/eye of healthy doctor or police personal by COVID-19 patients. This accidental ocular exposure (to biological fluid of a COVID-19 patient) may cause establishment of a systemic infection as mentioned in earlier part of this

Table 1 Details of studies evaluating the efficacy and safety of povidone iodine in COVID-19 (at different concentrations and different target populations in different settings, e.g., in vivo, in vitro)

\begin{tabular}{|c|c|c|c|}
\hline Study, author & Study type & Details of study & Outcome \\
\hline $\begin{array}{l}\text { Anderson DF, } \\
2020[11]\end{array}$ & In vitro & $\begin{array}{l}\text { Virucidal activity was evaluated by suspension assay } \\
\text { Contact time }=30 \mathrm{~s}\end{array}$ & $\begin{array}{l}\text { PVP-I at concentrations } 10 \%, 7.5 \%, 1 \% \text { and } 0.45 \% \text { exhibited } \\
\text { virucidal activity }(\geq 99.99 \%) \text { against SARS-CoV-2 }\end{array}$ \\
\hline $\begin{array}{l}\text { Bidra AS, } \\
\quad 2020[21]\end{array}$ & In vitro & $\begin{array}{l}\text { Compared the in vitro inactivation of SARS-CoV-2 } \\
\text { by } \mathrm{H} 2 \mathrm{O} 2 \text { and PVP-I } \\
\text { Contact time }=15 \text { and } 30 \mathrm{~s}\end{array}$ & $\begin{array}{l}\text { At both the contact times, PVP-I concentrations } 0.5,1.25 \text {, and } \\
1.5 \% \text { were successful in complete inactivation of the virus. } \\
\text { However minimal virucidal effect was seen in case of } \mathrm{H} 2 \mathrm{O} 2\end{array}$ \\
\hline $\begin{array}{l}\text { Bidra AS, } \\
2020[22]\end{array}$ & In vitro & $\begin{array}{l}\text { Investigated optimal concentration and contact time } \\
\text { of PVP-I required for SARS-CoV-2 cidal activity }\end{array}$ & $\begin{array}{l}\text { Complete inhibition was seen with } 15 \mathrm{~s} \text { contact period at } \\
\text { concentrations } 0.5,1 \text {, and } 1.5 \% \text {. The results were better than } \\
70 \% \text { ethanol }\end{array}$ \\
\hline $\begin{array}{l}\text { Liang B, } 2020 \\
\text { [23] }\end{array}$ & $\begin{array}{l}\text { In vitro } \\
\text { efficacy, } \\
\text { in vivo } \\
\text { toxicity }\end{array}$ & $\begin{array}{l}\text { In vitro evaluation and ocular toxicity study (in } \\
\text { rabbit) of PVP-I eye drop (gel forming) and PVP-I } \\
\text { nasal spray (gel forming) }\end{array}$ & $\begin{array}{l}\text { Dose and time dependent inactivation of SARS-CoV-2 was } \\
\text { seen in both the cases }\end{array}$ \\
\hline $\begin{array}{l}\text { Khan MM, } \\
2020[24]\end{array}$ & Clinical trial & $\begin{array}{l}\text { Evaluated safety of } 0.5 \% \text { PVP-I solution as nasal } \\
\text { drops }\end{array}$ & Povidone iodine $0.5 \%$ was well tolerated. \\
\hline $\begin{array}{l}\text { Lamas LM, } \\
2020[25]\end{array}$ & Clinical study & $\begin{array}{l}\text { Evaluations of the effect of povidone iodine mouth } \\
\text { wash against COVID-19 }\end{array}$ & $\begin{array}{l}\text { Lowering of salivary SARS-CoV-2 load was seen following } \\
\text { PVP-I rinse }\end{array}$ \\
\hline NCT04371965 & $\begin{array}{l}\text { Clinical } \\
\text { trials.gov }\end{array}$ & $\begin{array}{l}\text { Evaluation of the effect of PVP-I nasal-spray, gurgle } \\
\text { and mouth wash on nasopharyngeal SARS-CoV-2 } \\
\text { load }\end{array}$ & $\begin{array}{l}\text { Name of study: KILLER. } \\
\text { Status: NYR }\end{array}$ \\
\hline NCT04410159 & $\begin{array}{l}\text { Clinical } \\
\text { trials.gov }\end{array}$ & $\begin{array}{l}\text { Evaluation of comparative efficacy of tap-water gur- } \\
\text { gle vs. PVP-I vs. essential oil gargle in patients } \\
\text { with COVID-19 }\end{array}$ & $\begin{array}{l}\text { Name of the study: GARGLES } \\
\text { Status: R }\end{array}$ \\
\hline NCT04449965 & $\begin{array}{l}\text { Clinical } \\
\text { trials.gov }\end{array}$ & Efficacy of PVP-I rinse on COVID-19 & Status: NYR \\
\hline NCT04347954 & $\begin{array}{l}\text { Clinical } \\
\text { trials.gov }\end{array}$ & $\begin{array}{l}\text { Evaluation of the efficacy of nasal spray of PVP-I on } \\
\text { nasopharyngeal titer of SARS-CoV-2 }\end{array}$ & Status: R \\
\hline NCT04364802 & $\begin{array}{l}\text { Clinical } \\
\text { trials.gov }\end{array}$ & Intranasal prophylaxis of PVP-I for HCWs & $\begin{array}{l}\text { Name: PIIPPI } \\
\text { Status: } \mathrm{R}\end{array}$ \\
\hline NCT04344236 & $\begin{array}{l}\text { Clinical } \\
\text { trials.gov }\end{array}$ & $\begin{array}{l}\text { Evaluation of effect of nasal rinses and gargling of } \\
\text { PVP-I on naso- and oropharyngeal SARS-CoV-2 } \\
\text { load }\end{array}$ & Status: R \\
\hline NCT04393792 & $\begin{array}{l}\text { Clinical } \\
\text { trials.gov }\end{array}$ & Sinus-wash for COVID-19 & Status: $\mathrm{R}$ \\
\hline NCT04446104 & $\begin{array}{l}\text { Clinical } \\
\text { trials.gov }\end{array}$ & $\begin{array}{l}\text { Evaluation of preventive effect in migrant workers } \\
\text { (high risk group) }\end{array}$ & Status: $\mathrm{R}$ \\
\hline NCT04341688 & $\begin{array}{l}\text { Clinical } \\
\text { trials.gov }\end{array}$ & Effect of gargle on intra-oral SARS-CoV-2 load & $\begin{array}{l}\text { Name: GARGLES } \\
\text { Not yet recruiting }\end{array}$ \\
\hline
\end{tabular}

$P V P-I$ povidone iodine, $R$ recruiting, NYR not yet recruiting 
letter. It is to be mentioned that in our study [19], we are not talking about use of povidone iodine for decreasing the infectivity of ocular fluid in COVID-19 patients. As COVID-19 patients are already in quarantine or isolation, this might be an unnecessary approach. Rather we are talking on accidental ocular exposure to SARS-CoV-2 in case of a healthy individual.

Regarding the virucidal and bactericidal activities of povidone iodine, it showed bactericidal activity against $\mathrm{S}$. pneumonia and $\mathrm{K}$. pneumonia and antiviral effect against H1N1, rotavirus, MERS-CoV and SARS-CoV (contact time $=15 \mathrm{~s}$ ) at a concentration as low as $0.23 \%$ [20]. Although in our earlier letter [19], we have extrapolated data from SARS-CoV to SARS-CoV-2 (due to nonavailability of data against SARS-CoV-2); however, at the time of this current letter, we have definitive data regarding the antiviral effect of povidone iodine against SARS-CoV-2 and different effective concentrations. We searched three databases "PubMed, clinicaltrials.gov and Google scholar" using keywords "povidone iodine" and COVID-19. The details of studies evaluating the safety and efficacy of povidone iodine at different doses against SARS-CoV-2 are showed in Table 1. The findings of these studies highlight the utility of povidone iodine and may help us deciding the effective dose and tolerability of povidone iodine against SARS-CoV-2.

Many experts are now recommending PVP-I as a publichealth-intervention for COVID-19 [26]. In oncology practice, especially among head and neck surgeons, there is a demand for considering it as a component of PPE (personal-protectionequipment) [27]. Some studies also recommended use of povidone iodine eye drop; however, the population group which could be beneficial was not well defined [28]. However, povidone iodine is never an alternative to the use of PPEs like protective goggles and wearing of PPF kits at this current point of time.

Agarwal R et al. have mentioned that the course of COVID-19-related conjunctivitis is self-limiting and apparently benign. We should note that the course of COVID-19associated conjunctivitis is not a smooth road always with few of the patients requiring mild steroid [29] and even relapsing conjunctivitis is also reported [30].

Now coming to another issue of utility of povidone iodine eye drop in COVID-19-associated conjunctivitis, although covid-19-associated conjunctivitis is considered a possible benign disease, however, many have tried ribavirin eye drop [31] and ganciclovir [5, 30]. However, clinical efficacy of ganciclovir in COVID-19 is dubious [32]. In COVID-19associated conjunctivitis, most of the bodies recommended artificial tear; however, if symptoms persisted, a mild steroid could be considered [29]. Regarding use of anti-viral agent, if at all required, povidone iodine may stand a chance; however, comparative clinical data with the standard of care (e.g., artificial tear drop) and mild steroid will be needed. The concentration of povidone iodine to reduce infectivity of SARS-CoV is as low as $0.23 \%$ [20], and for SARS-CoV-2, it is as low as $0.45 \%$ [11]. Although irritation is a common occurrence during the use of povidone iodine eye drop, which necessitates the use of topical anesthetics at priori; however, at these low concentrations of povidone iodine, the side effect and irritability profile of povidone iodine need to be reevaluated. Again, no corneal toxicity was observed at a dose of povidone iodine $0.5 \%$ [33].

\section{Compliance with ethical standards}

Conflict of interest The authors declare that they have no conflict of interest.

Abbreviations 2019-nCoV, 2019 novel corona virus; SARS-CoV, Severe acute respiratory syndrome coronavirus; MERS-CoV, Middle East respiratory syndrome coronavirus; ACE2, Angiotensin converting enzyme 2; COVID-19, Coronavirus disease-2019; PVP-I, Povidone iodine; PPE, Personal protective equipment

\section{References}

1. Xie H-T, Jiang S-Y, Xu K-K et al (2020) SARS-CoV-2 in the ocular surface of COVID-19 patients. Eye Vis 7:23. https://doi. org/10.1186/s40662-020-00189-0

2. Wu P, Duan F, Luo C et al (2020) Characteristics of ocular findings of patients with coronavirus disease 2019 (COVID-19) in Hubei Province, China. JAMA Ophthalmol 138:575-578. https://doi.org/ 10.1001/jamaophthalmol.2020.1291

3. Sarma P, Kaur H, Kaur H et al (2020) Ocular manifestations and tear or Conjunctival swab PCR positivity for 2019-nCoV in patients with COVID-19: a systematic review and meta-analysis. Social Science Research Network, Rochester

4. Loon S-C, Teoh SCB, Oon LLE et al (2004) The severe acute respiratory syndrome coronavirus in tears. Br J Ophthalmol 88: 861-863. https://doi.org/10.1136/bjo.2003.035931

5. Zhang X, Chen X, Chen L et al (2020) The evidence of SARSCoV-2 infection on ocular surface. Ocul Surf 18:360-362. https:// doi.org/10.1016/j.jtos.2020.03.010

6. Wei D, Bao L, Xiang Z et alRhesus macaques can be effectively infected with SARS-CoV-2 via ocular conjunctival route. https:// doi.org/10.1101/2020.03.13.990036

7. Prajapat M, Sarma P, Shekhar N et al (2020) Update on the target structures of SARS-CoV-2: a systematic review. Indian J Pharm 52: 142. https://doi.org/10.4103/ijp.IJP_338_20

8. Ma D, Chen C-B, Jhanji V et al (2020) Expression of SARS-CoV-2 receptor ACE2 and TMPRSS2 in human primary conjunctival and pterygium cell lines and in mouse cornea. Eye 34:1212-1219. https://doi.org/10.1038/s41433-020-0939-4

9. Prajapat M, Sarma P, Shekhar N et al (2020) Drug targets for corona virus: a systematic review. Indian J Pharm 52:56. https://doi. org/10.4103/ijp.IJP_115_20

10. Danesh Mesgaran S, Sharbati J, Einspanier R, Gabler C (2016) mRNA expression pattern of selected candidate genes differs in bovine oviductal epithelial cells in vitro compared with the in vivo state and during cell culture passages. Reprod Biol Endocrinol 14:44. https://doi.org/10.1186/s12958-016-0176-7

11. Zaitseva M, Vollenhoven BJ, Rogers PAW (2006) In vitro culture significantly alters gene expression profiles and reduces differences 
between myometrial and fibroid smooth muscle cells. Mol Hum Reprod 12:187-207. https://doi.org/10.1093/molehr/gal018

12. Lange C, Wolf J, Auw-Haedrich C et alExpression of the COVID19 receptor ACE2 in the human conjunctiva. J Med Virol n/a. https://doi.org/10.1002/jmv.25981

13. Zhou L, Xu Z, Castiglione GM et al (2020) ACE2 and TMPRSS2 are expressed on the human ocular surface, suggesting susceptibility to SARS-CoV-2 infection. Ocul Surf 18:537-544. https://doi. org/10.1016/j.jtos.2020.06.007

14. Li S, Li D, Fang J et alCOVID-19 receptor ACE2 is expressed in human conjunctival tissue, expecially in diseased conjunctival. 28

15. Chen L, Liu M, Zhang Z et al (2020) Ocular manifestations of a hospitalised patient with confirmed 2019 novel coronavirus disease. Br J Ophthalmol 104:748-751. https://doi.org/10.1136/ bjophthalmol-2020-316304

16. Sun C, Wang Y, Liu G, Liu Z (2020) Role of the eye in transmitting human coronavirus: what we know and what we do not know. Front Public Health 8. https://doi.org/10.3389/fpubh.2020.00155

17. Transmission of SARS-CoV-2: implications for infection prevention precautions. https://www.who.int/news-room/commentaries/ detail/transmission-of-sars-cov-2-implications-for-infectionprevention-precautions. Accessed 14 Jul 2020

18. Lu C, Liu X, Jia Z (2020) 2019-nCoV transmission through the ocular surface must not be ignored. Lancet 395:e39. https://doi. org/10.1016/S0140-6736(20)30313-5

19. Sarma P, Kaur H, Medhi B, Bhattacharyya A (2020) Possible prophylactic or preventive role of topical povidone iodine during accidental ocular exposure to 2019-nCoV. Graefes Arch Clin Exp Ophthalmol. https://doi.org/10.1007/s00417-020-04752-2

20. Eggers M, Koburger-Janssen T, Eickmann M, Zorn J (2018) In vitro bactericidal and virucidal efficacy of povidone-iodine gargle/mouthwash against respiratory and oral tract pathogens. Infect Dis Ther 7:249-259. https://doi.org/10.1007/s40121-0180200-7

21. Bidra AS, Pelletier JS, Westover JB et al (2020) Comparison of in vitro inactivation of SARS CoV-2 with hydrogen peroxide and Povidone-iodine Oral antiseptic rinses. J Prosthodont. https://doi. org/10.1111/jopr.13220

22. Bidra AS, Pelletier JS, Westover JB et al (2020) Rapid in-vitro inactivation of severe acute respiratory syndrome coronavirus 2 (SARS-CoV-2) using Povidone-iodine Oral antiseptic rinse. J Prosthodont. https://doi.org/10.1111/jopr.13209

23. Liang B, Yuan X, Wei G et al (2020) In-vivo toxicity studies and invitro inactivation of SARS-CoV-2 by Povidone-iodine in-situ gel forming formulations. bioRxiv. https://doi.org/10.1101/2020.05. 18.103184
24. Khan MM, Parab SR, Paranjape M (2020) Repurposing 0.5\% povidone iodine solution in otorhinolaryngology practice in Covid 19 pandemic. Am J Otolaryngol 41:102618. https://doi. org/10.1016/j.amjoto.2020.102618

25. Martínez Lamas L, Diz Dios P, Pérez Rodríguez MT et al (2020) Is povidone-iodine mouthwash effective against SARS-CoV-2? First in vivo tests. Oral Dis. https://doi.org/10.1111/odi.13526

26. Kronbichler A, Effenberger M, Eisenhut $M$ et al (2020) Seven recommendations to rescue the patients and reduce the mortality from COVID-19 infection: an immunological point of view. Autoimmun Rev 19:102570. https://doi.org/10.1016/j.autrev. 2020.102570

27. Mady LJ, Kubik MW, Baddour K et al (2020) Consideration of povidone-iodine as a public health intervention for COVID-19: utilization as "personal protective equipment" for frontline providers exposed in high-risk head and neck and skull base oncology care. Oral Oncol 105:104724. https://doi.org/10.1016/j. oraloncology.2020.104724

28. Contini C, Enrica Gallenga C, Neri G et al (2020) A new pharmacological approach based on remdesivir aerosolized administration on SARS-CoV-2 pulmonary inflammation: a possible and rational therapeutic application. Med Hypotheses 144:109876. https://doi. org/10.1016/j.mehy.2020.109876

29. Management of conjunctivitis during the COVID 19 pandemic 2020. Aust J Gen Pract. https://www1.racgp.org.au/ajgp/ coronavirus/management-of-conjunctivitis-during-the-covid-19-p. Accessed 14 Jul 2020

30. Guo D, Xia J, Wang Y et al (2020) Relapsing viral keratoconjunctivitis in COVID-19: a case report. Virol J 17. https://doi.org/10. 1186/s12985-020-01370-6

31. (2020) Case study links COVID-19 to follicular conjunctivitis. In: American Academy of Ophthalmology. https://www.aao.org/ editors-choice/case-study-links-covid-19-to-follicular-conjunctiv. Accessed 14 Jul 2020

32. Guo Y-R, Cao Q-D, Hong Z-S et al (2020) The origin, transmission and clinical therapies on coronavirus disease 2019 (COVID-19) outbreak - an update on the status. Mil Med Res 7:11. https://doi. org/10.1186/s40779-020-00240-0

33. Freitas D, Santos N, Sousa L et al (2002) Corneal toxicity of povidone-iodine eye drops. Invest Ophthalmol Vis Sci 43:42184218

Publisher's note Springer Nature remains neutral with regard to jurisdictional claims in published maps and institutional affiliations. 